\title{
Study of TGFBI gene mutations in Ukrainian patients with corneal dystrophies
}

\author{
V.M. Pampukha, G.I. Drozhyna ${ }^{1}$, L.A. Livshits
}

Institute of Molecular Biology and Genetics of National Academy of Sciences of Ukraine 150, Zabolotny Str., Kyiv, 03680, Ukraine

${ }^{1}$ The V.P. Filatov institute of eye diseases and tissue therary of Academy of Medical sciences of Ukraine 49/51,Frantcuzkiy Bulvar, Odessa, 65061, Ukraine

livshits@imbg.org.ua

\begin{abstract}
In this study Arg124Cys (exon 4), Thr538Arg, Ala546Thr, Arg555Thr, ARg55Gln (exon 12), His626Arg (exon 14) mutations of the TGFBI gene were analyzed using polymerase chain reaction followed by restriction digestion in 91 patients with different forms of corneal dystrophy and 31 clinically healthy individuals from 49 unrelated families. Our results show that TGFBI gene mutations analysis is important for differential diagnostics of corneal dystrophies with prognostic and therapeutic implications as well as for genetic consulting in high risk families.
\end{abstract}

Keywords: TGFBI gene, keratoepithelin, corneal dystrophy

Introduction. TGFBI gene, or $B I G-H 3$ (transforming growth factor-beta induced gene) was discovered in 1992 by Skonier et al. while studying the influence of transforming growth factor-beta on the cell lines of human adenocarcinoma [1]. Two years later independent investigations in two laboratories revealed tgfbi protein in cornea as well $[2,3]$. In the same year three kinds of dystrophy of corneal stroma, namely, lattice dystrophy (type I), granular dystrophy (type I), and Avellino dystrophy were mapped on chromosome 5 [4]. Finally, in 1997 Munier et al. determined that

(C) V.M. PAMPUKHA, G.I. DROZHYNA, L.A. LIVSHITS, 2008 four types of dystrophy of corneal stroma (three aforementioned plus Reis-Bucklers' dystrophy) were caused by different mutations in TGFBI gene [5]. This gene was found to locate on the long arm of chromosome $5(5 \mathrm{q} 31)$ and to encode extracellular matrix protein, consisting of 683 amino acid residues. Munier et al. called this protein "keratoepithelin" because they believed it was expressed in cornea solely. However, tgfbi protein was found also in other tissues of the organism $[1,6]$. Its carboxylic end contains Arg-Gly-Asp sequence (RGD-motive), which is recognized by surface receptor proteins - integrins $[7,8]$. Different investigations revealed covalent bond between tgfbi protein and collagen VI in many tissues, 
including cornea $[9,10]$, besides, it interacts with fibronectin [11]. Tertiary structure of tgfbi protein is similar to that of fasciclin I - protein, performing adhesive function in nervous cells of insects [12]. Aforementioned proteins belong to a large family, which is specific for the presence of tandem-repeated homologous sequences, so called FAS1-domains. Tgfbi protein consists of four such domains [13].

Hereditary corneal dystrophies are a heterogeneous group of progressing diseases, resulting in corneal opacities and significant loss of vision. Dystrophies of corneal stroma, caused by mutations in TGFBI gene, are autosomal dominant diseases, characterised by a common feature - the presence of abnormal deposits, localized either in keratocytes or among collagen fibrils [14]. Lattice dystrophy is specific for amyloid deposits, granular dystrophy is characterised by hyaline deposits, while Avellino dystrophy is notable for both amyloid and hyaline deposits [15].

Most patients with corneal dystrophy have mutations in codons 124 and 555 of TGFBI gene. Besides, genetic investigations showed correlation between some types of TGFBI mutations and clinical forms of dystrophy, caused by them [5, 16-18].For instance, mutation Arg124Cys is specific for lattice dystrophy (type I), mutation Arg124His - for Avellino dystrophy, mutation Arg124Leu - for Reis-Bucklers' dystrophy, mutation Arg555Trp - for granular dystrophy (type I), Arg555Gln - for Thiel-Behnke dystrophy. The study on the relations of genotype and phenotype revealed that homozygosity for mutations in $T G F B I$ gene causes more early onset and more complicated clinical course [19, 20].

Lattice dystrophy is the most widely spread kind of dystrophy, which as a rule is a bilateral amyloidosis, characterized by refractive lattice lines. Mutations in TGFBI gene cause several types of lattice dystrophy. Lattice dystrophy (type I) is a bilateral symmetrical disease of cornea, characterized by numerous semi-transparent thin lattice lines, associated with white spots in surface and middle layers of central stroma. It was established that symptoms appeared in $1^{\text {st }}-2^{\text {nd }}$ decade of life. Patients with this form of disease often suffer from relapses of erosive processes [21-23]. It was shown that most patients with this type of disease have mutation Arg124Cys, however, this phenotype may be associated with other mutations, including Leu518Arg, Leu569Arg, and Val539Asp [24-26].

In 1991 Stock et al. described a type of dystrophy, specific for late onset and thick lattice formations [27]. In this case corneal erosions are an inconstant sign. This type of dystrophy is defined as lattice dystrophy (type IIIA), associated with mutations Pro501Thr (spread among Japanese), Ala546Thr ( among French), Asn622Lys, ASN622His ( the population of the British Isles) [28-30]. In 1999 the authors of [31] identified mutation His626Arg of $T G F B I$ gene in patients with late onset of lattice dystrophy. In this case the dynamics of clinical onsets in both eyes was asynchronic, i.e. asymmetrical. Schmitt-Bernard et al. studied clinical, histological, and ultrastructural specificities of dystrophy, caused by this mutation, and came to the conclusion that this type of dystrophy is a separate group of lattice dystrophies - intermediary between types I and IIIA, characterized by a more early onset $\left(3^{\text {rd }}-4^{\text {th }}\right.$ decade of life $)$ and thinner lattice-like lines compared to type IIIA [32].

Fujiki et al. described so called deep form of lattice dystrophy and distinguished it as the $4^{\text {th }}$ type. Its first clinical manifistation is shown in the $5^{\text {th }}$ life decade. They are characterized by deposits of star-like form, located in deep layers of stroma. Radial lattice-like structures in middle layers of stroma occur later, while in the higher layers of stroma and epithelium deposits are completely absent. Different authors showed this type to be associated with mutations Leu527Arg (notable for Japanese), Val631Asp (specific for Italian), and Gly594Val (found in India) [26, 30, 33].

Other autosomal dominant diseases, caused by mutations in TGFBI gene, are granular corneal dystrophies [23, 34]. Clinical picture of classical granular dystrophy (type I, or Groenouw I), is notable for grey-white non-transparent knots, resembling bread crumbs, in corneal stroma. The first disease signs are revealed in the $1^{\text {st }}-2^{\text {nd }}$ life decade. With age their number and size increase, in some places they merge and spread into middle and deep layers of stroma $[35,36]$. Some patients have erosive 
processes in cornea and pain syndrome [37]. The majority of patients with granular dystrophy (type I) are found to have mutation Arg555Trp [5]. Mutation Arg124Ser was discovered only in two families with this type of dystrophy [38]. In case of Avellino dystrophy manifestation of clinical signs starts in the $1^{\text {st }}-3^{\text {rd }}$ life decades. In young age abnormal formations in cornea of patients with Avellino dystrophy are in the form of circles, disks, snowflakes, stars, located in front and middle layers of stroma. Lattice-like formations appear later, they are localized in the middle and deep layers of stroma $[39,40]$. All the patients with this type of dystrophy are found to have only one mutation - Arg124His [5].

Reis-Bucklers' dystrophy is also called dystrophy of Bowman's layer, type I. Disease symptoms, including relapsing erosion and expressed pain syndrome, start in the first life decade. Light microscopy allows observing degeneration of basal epithelium and Bowman's layer, which are completely or partially substituted by connective tissue. Hyaline deposits, located under epithelium, destroy Bowman's layer. Electronic microscopy reveals dense rod-like granules, ultrastructural characteristics of which correspond to granular dystrophy of corneal stroma [41, 42].

At present three mutations, namely, Arg124Leu, deltaF540, and Gly623Asp, are known to be associated with Reis-Bucklers' dystrophy [43-45]. Light microscopy of cornea of patients with Thiel-Behnke dystrophy allows observing clinical picture, similar to Reis-Bucklers' dystrophy. It is noteworthy that both kinds of dystrophy affect the same corneal layer and differ only in morphology . In case of Thiel-Behnke dystrophy subepithelial deposits enter epithelium in the form of numerous wedges, resembling saw teeth. Electronic microscopy shows curly filaments [46, 47]. Only one mutation Arg555Gln of TGFBI gene is associated with Thiel-Behnke dystrophy, however, this type of dystrophy may be caused by mutations in another gene, mapped on chromosome 10 (10q23-q24) [5, 48].

More than 30 mutations are identified in TGFBI gene. The majority of them are located in exons 4,12 , and 14. Investigations on the association of certain mutant variants and clinical characteristics of corneal dystrophy are important for both determination of the function of tgfbi protein, and the analysis of mechanisms of disease pathogenesis. In its turn, the results of such investigations allow to improve differential diagnostics and prognosis of clinical course.

The aim of our work was to study mutations Arg124Cys (exon 4), Thr538Arg, Ala546Thr, Arg555Thr, Arg555Gln (exon 12), and His626Arg (exon 14) of TGFBI gene in patients with different clinical forms of corneal dystrophy.

Materials and Methods. Clinical and molecular-genetic investigations were performed with 91 patients with hereditary dystrophy of corneal stroma from 49 families, and with 31 clinically healthy family members of patients. The investigated group included 45 patients and 11 healthy persons from 20 families with lattice dystrophy (type I), 16 patients and 1 healthy person from 10 families with granular dystrophy (type I), 4 patients from 2 families with the clinical diagnosis of Reis-Bucklers' dystrophy, 26 patients and 18 healthy persons from 17 families with lattice dystrophy and late onset.

The materials for molecular-genetic investigation were samples of peripheral blood, obtained at the conditions of informed consent of the individuals from the investigated group. The materials for morphological and histochemical investigation were corneal disks, obtained after performed keratoplasty. Histochemical and ultrastructural analyses were conducted as described in [49].

DNA preparations were extracted from leukocytes of peripheral blood and purified by the standard method of phenol-chloroform extraction [50].

To analyse mutant variants of TGFBI gene we conducted specific in vitro amplification of DNA-sequences of exons 4, 12, and 14 by the method of polymerase chain reaction (PCR) [51] in automatic regime on Perkin Elmer thermocycler (Cetus, USA) according to the following scheme: denaturation of DNA $-45 \mathrm{sec}, 94^{\circ} \mathrm{C}$; annealing of primers $-45 \mathrm{sec}, 55^{\circ} \mathrm{C}$; elongation $-1 \mathrm{~min}, 72^{\circ} \mathrm{C}$. 


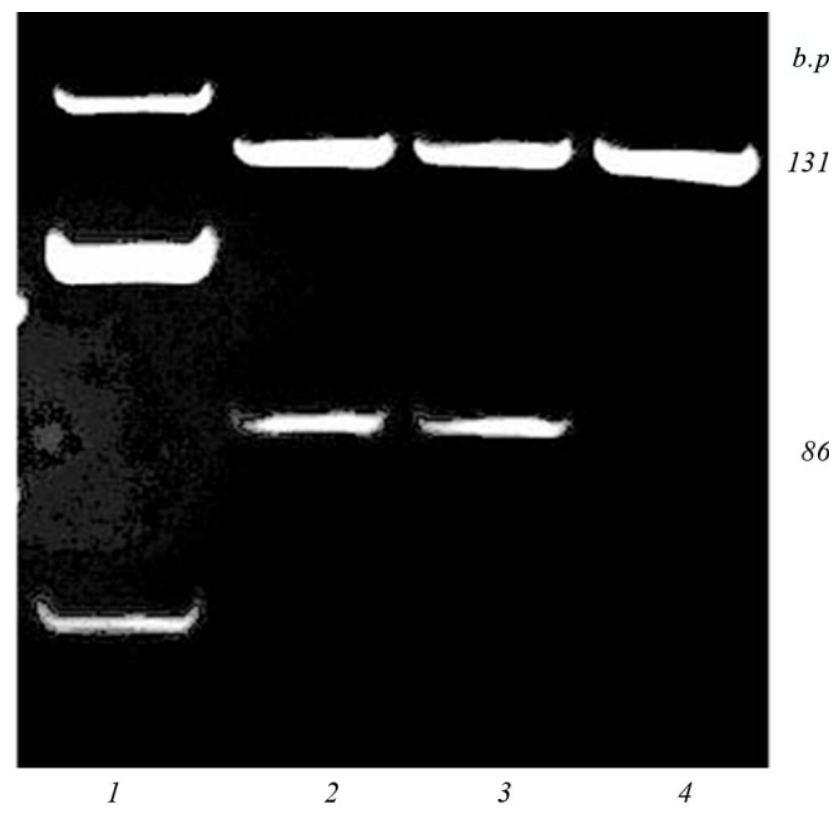

Fig.1 Analysis of mutation $R 555 \mathrm{~W}$ in exon 12 of $T G F B I$ gene in patients with granular dystrophy (PCR + BstXI; 10\% PAAG): 1 - marker of molecular weight $p U C 19 D N A / M s p I ; 2,3$ - patients; 4 - healthy individuals

Specific oligonucleotides, synthesized in accordance to corresponding exon sequences of $T G F B I$ gene, were used as primers:

for mutation Arg124Cys forward (5 -CAGAGGCCATCCCTCCTTCT-3), reverse (5 -CAGGCCTCAGCTTCTCCCTG-3);

for mutations Thr538Arg, Ala546Thr, Arg555Thrforward (5 -GGACTGACGGAGACCCTCAA-3), reverse (5 -GGAGACGTGTACTTAAGTTGGTC-3 );

for mutation Arg555Gln forward (5 -GGACTGACGGAGACCCTCAA-3 ), reverse (5 -CTTTACCCAAGAGTCAGATC-3 );

for mutation Hys626Arg forward (5 -GAAAAACAATGTGGTGAGTGTC-3 ), reverse (5 -CATGGAGAAAAGGACTGGCTG-3 ).

To perform differential analysis of some types of mutations, amplified sequences of exons 4, 12, and 14 were hydrolyzed by restriction endonucleases PstI, HinfI, MwoI, BstXI, BglII, NlaIII for mutations Arg124Cys, Thr538Arg, Ala546Thr, ARg555Thr, ARg555Gln, Hys626Arg, respectively.

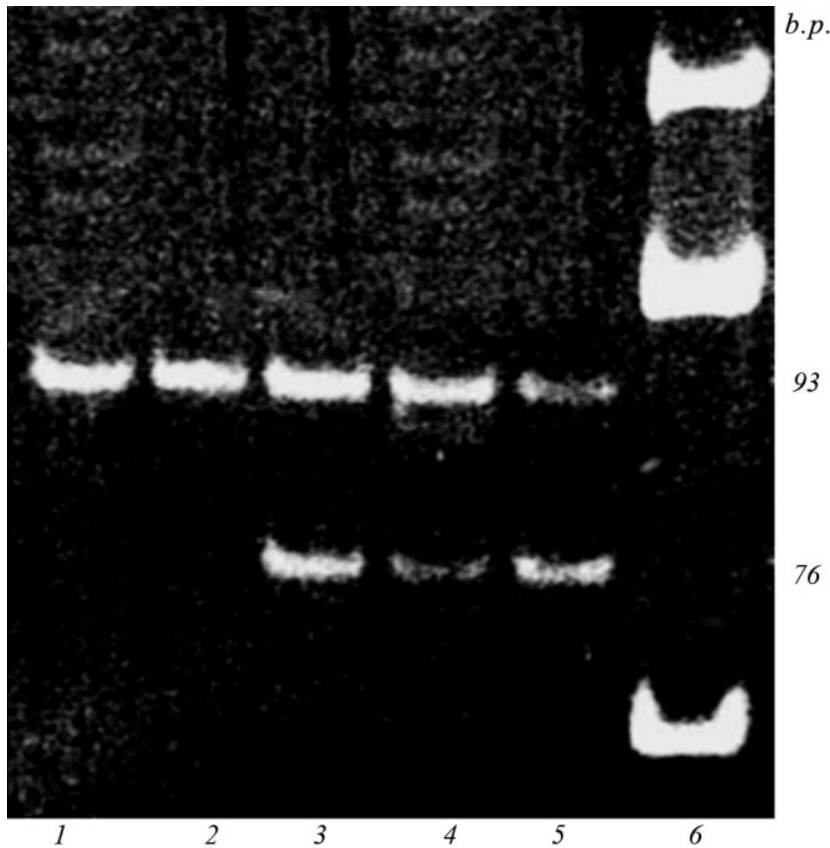

Fig. 2 Analysis of mutation $R 124 C$ in exon 4 of $T G F B I$ gene in patients with lattice corneal dystrophy (PCR + PstI; 10\% PAAG): 1, 2- healthy individuals; 3, 4, 5 - patients; 6 - marker of molecular weight pUC19DNA/MspI

Results and Discussion. Molecular-genetic analysis of exon 12 of TGFBI gene revealed mutation Arg555Thr in five families with clinical diagnosis of granular corneal dystrophy, including the case of a 9-year-old child (Fig.1). Other five families with clinical diagnosis of granular dystrophy did not have mutation R555W, specific for this dystrophy kind. Detailed study of clinical picture in four families showed clinical signs, notable for macular corneal dystrophy. Besides, it is possible to forecast autosomal recessive type of inheritance in these families. Therefore, the analysis of genealogy and phenotypic signs of disease with the consideration of the data of molecular-genetic analysis allowed reviewing the primary diagnosis.

Clinical and genealogic analysis of all the patients with lattice dystrophy demonstrated the autosomal dominant type of inheritance. Histochemical investigations were performed on the material of cornea after keratoplasty. Patients with clinical diagnosis of lattice corneal dystrophy showed morphological and ultrastructural features, specific for this kind of dystrophy [49]. 


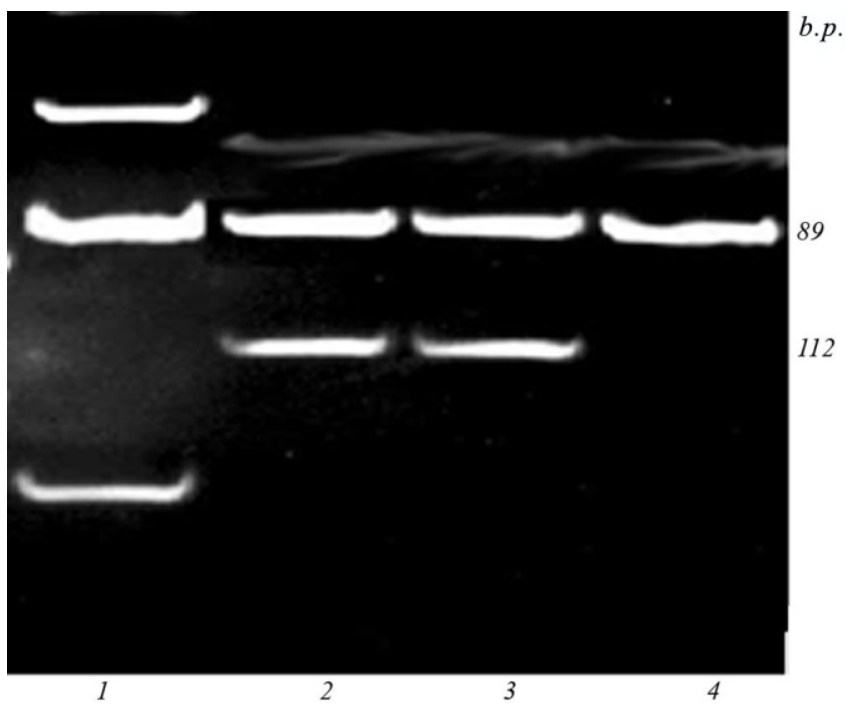

Fig.3 Analysis of mutation $R 555 Q$ in exon 4 of TGFBI gene (PCR + BglII; 10\% PAAG): 1 - marker of molecular weight $p U C 19 D N A / M s p I$; 2, 3 - heterozygous mutation carriers; 4 - healthy individual

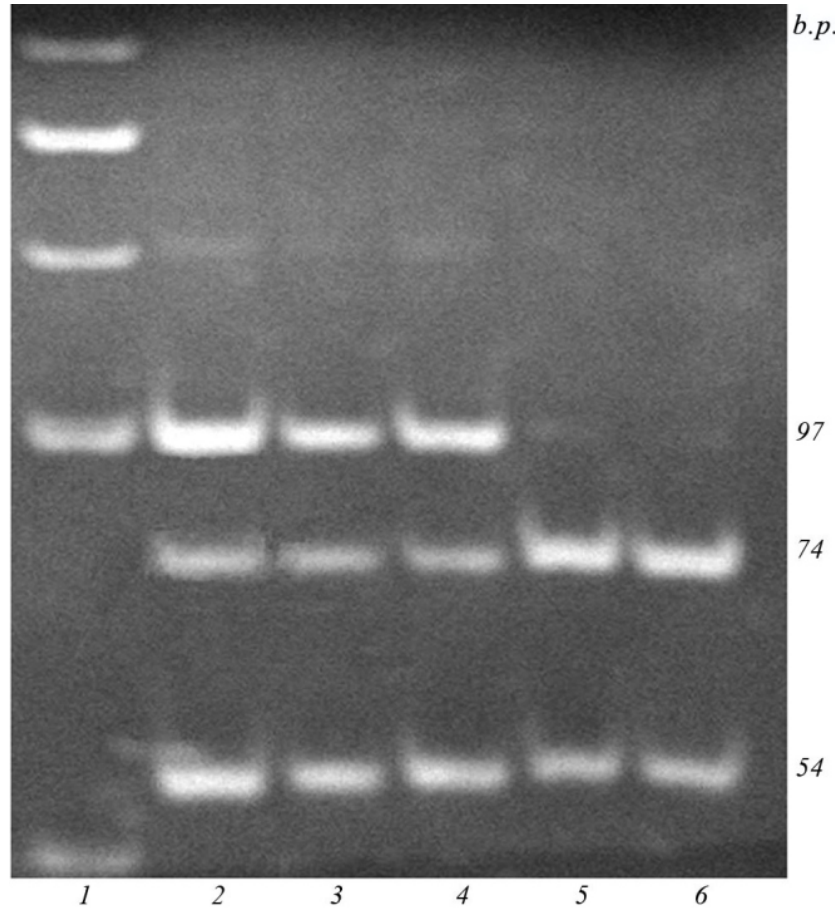

Fig.4 Analysis of mutation H626R in exon 14 of TGFBI gene in patients with lattice corneal dystrophy (PCR + NlaIII; 10\% PAAG): 1 - marker of molecular weight GeneRuler 50bp DNA Ladder; 2, 3, 4-patients; 5 , 6 - healthy individuals

Molecular-genetic analysis of exon 4 of TGFBI gene allowed determining mutation Arg124Cys in patients of 15 families and one 11-year-old child, who did not have clinical signs of lattice dystrophy, type I (Fig.2). Besides, this mutation was found in a patient with clinical diagnosis of Reis-Bucklers' dystrophy. Since mutation Arg124Cys causes the development of lattice dystrophy (type I), the primary diagnosis of this patient was reviewed. Five families with clinical diagnosis of lattice dystrophy (type I) did not have mutation Arg124Cys. Another family with the primary clinical diagnosis of Reis-Bucklers' dystrophy had mutation Arg555Gln, associated with Thiel-Behnke dystrophy (Fig.3). The primary clinical diagnosis of this family was also changed. Similarity of clinical pictures for Thiel-Behnke dystrophy and Reis-Bucklers' dystrophy, as well as similar early onsets of these kinds of dystrophy and lattice dystrophy are reasons of wrong diagnoses.

We did not identify mutation Ala546Thr using molecular-genetic analysis in any investigated patients with late onset of corneal dystrophy. It was found only in French patients [29].

The investigations performed determined mutation Hys626ARg in patients from 12 families; only in one family with primary clinical diagnosis of lattice dystrophy (type IIIA) this mutation was not revealed (Fig.4). Besides, the mutation was found in six persons who did not have clinical signs of disease yet. It is worth mentioning that mutation Hys626Arg was also found in one patient with the clinical diagnosis of lattice dystrophy (type I) which afforded grounds for doubting the sufficiency of data of clinical investigation to define correct diagnosis and identify the form of the disease. This assumption is also favoured by the results of the analysis of mutation Thr538ARg in the investigated group of patients. This mutation was not found in any patients with late onset of lattice dystrophy. However, mutation Thr538Arg was found in a patient with clinical diagnosis of lattice dystrophy, type I (Fig.5). Munier et al. supposed that mentioned mutation, discovered by Othenin-Girard et al, similar to mutation Hys626Arg, may be associated with the intermediary, type I/IIIA $[30,52]$. It is interesting that patients from four families with mutation Hys626Arg were characterized by so called asymmetry of clinical picture. It was evident from the fact that pathological deposits were observed in one eye first, and only in 


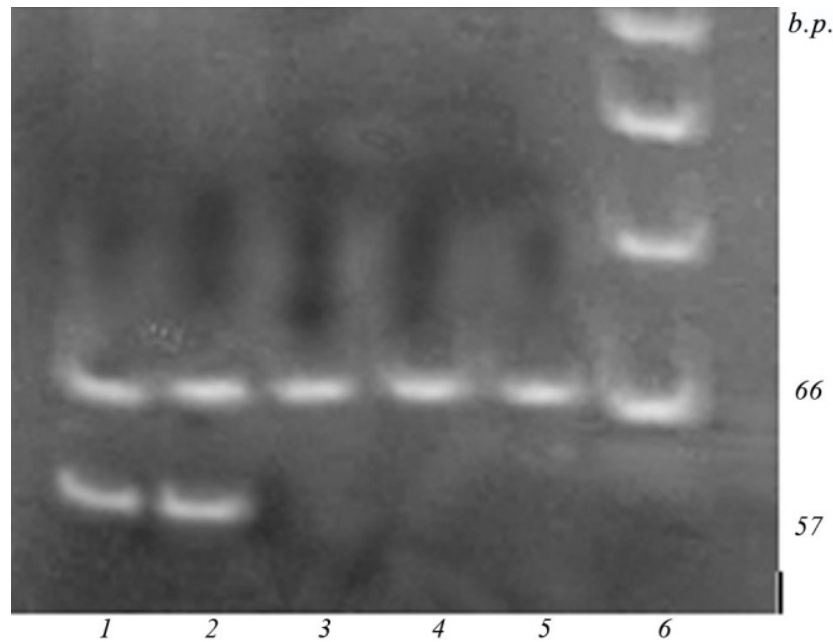

Fig.5 Analysis of mutation T538R in exon 12 of TGFBI gene in patients with lattice corneal dystrophy (PCR + Hinf $; 10 \%$ PAAG): $1,2-$ patients; $3,4,5$ - healthy individuals; 6 - marker of molecular weight pUC19DNA/MspI

several years slight manifestations of lattice dystrophy may be found in the other eye. At present nobody suggests a possible mechanism of these processes, therefore, detailed study of the structure and features of mutant protein and its interaction with protein-partners may clarify the nature of the asymmetry phenomenon.

Four of investigated families had characteristic symptoms of lattice dystrophy (type IV). None of them had mutations.

Clout and Hohenester believe that hot spots for mutations in positions Arg124 and Arg555 are located in the sequence, encoding the binding site of 6-spirals in protein domains 1 and 4, and substitutions of these amino acid residues destroy stability and solubility of the protein rather than its structure [13]. Mutations Arg124His and Arg124Cys cause the formation of amyloid deposits, but other mutations in positions Arg124 and Arg555 make the protein more hydrophobic and thus lead to the formation of hyaline deposits. On the other hand, some researchers believe that most mutations, located in the $4^{\text {th }}$ Fas 1 -domain, have more significant influence on the protein structure, since they are located in conservative positions. However, this assumption does not explain insignificant destruction of the protein structure by mutations in other three homologous domain of tgfbi.
The results of modelling the tertiary structure of domain 4 of tgfbi protein allowed assuming that mutation Thr538Arg, resulting in the substitution of threonine for arginine, causes the disorder in folding of protein product, which, in its turn, makes protein secretion impossible [13]. The authors of this work consider that amyloid deposits in patients with this mutation should appear in the first life decade. However, we revealed mutation Thr538Arg in a patient, whose disease manifestation appeared in the third life decade.

Basing on the results of modelling, we came to the conclusion that protein secretion becomes impossible when mutation Ala546Thr occurs, because this mutation results in its significant destabilization. Mutation His626Arg destroys hydrogen bonds. Besides, conservatism of histidine in this position, observed in domains of all proteins of Fas1-superfamily, testifies to its significance for the process of folding, therefore, it is not likely that the protein with mutation His626Arg will be folded and secreted. Taking into consideration forecasted functions of mutant proteins, determined by the results of modelling tertiary structure, it is possible to assume that patients with mutations Thr538Arg and His626Arg will have early onset. However, the data obtained by us, do not support such assumption. All our patients with mentioned mutations, except for one case with the primary clinical diagnosis of lattice dystrophy, type I, and early onset, had the beginning of disease manifestation in the $3^{\text {rd }}-4^{\text {th }}$ life decade.

The accumulation of mutant protein tgfbi in the form on insoluble deposits takes place only in cornea, though this protein is expressed in other tissues as well, therefore, it is possible to assume that tissue-specific factors are involved in pathogenesis. It is yet to be discovered why mutations in one gene or even mutations in one codon are capable of inducing such different phenotypic manifestations. For instance, in case of substituting arginine in codon 124 for cysteine, leucine, histidine, the deposits of amyloid, hyaline or mixed deposits are formed in cornea.

Previously the diagnosis of different forms of hereditary corneal dystrophy was made on the basis of specific clinical picture as well as typical morphological and histochemical features. Taking into 
account that morphological and histochemical investigations using the material of cornea are possible only after keratoplasty, the main role in setting the diagnosis in pre-surgery period is given to the clinical picture of disease.

Molecular-genetic analysis of mutations in TGFBI gene is highly informative for the purpose of accurate differential diagnostics of hereditary dystrophy of corneal stroma, it is also very important for performing pre-symptomatic diagnostics in the members of patient family and forecasting the clinical course with corresponding therapy.

The obtained data on the association of mutant variants of TGFBI gene and clinical signs of dystrophy of corneal stroma give reasonable grounds for conclusion that the efforts in understanding pathogenesis of this disease should be directed onto the determination of the nature of interaction of tissue-specific factors and mutant protein tgfbi in cornea, as well as onto the clarification of factors, influencing its structure and stability.

\section{В. М. Пампуха, Г. І. Дрожжина, Л. А. Лівшиць}

Дослідження мутацій гена $T G F B I$

у хворих на дистрофію строми рогівки,

які проживають в Україні

Резюме

Проаналізовано мутаиіï Arg124Cуs (екзон 4), Thr538Arg, Ala546Thr, Arg555Thr, Arg55Gln (екзон 12), His626Arg (екзон 14) гена TGFBI з використанням методу полімеразної ланцюгової реакиії з наступною рестрикиією у 91 пацієнта з різними формами дистрофії рогівки та 31 клінічно здорового індивіда з 49 неспоріднених родин. Отримані результати показують, щио аналіз мутацій в гені TGFBI має важливе значення у диференційній діагностиці дистрофій рогівки з прогностичним $i$ терапевтичним застосуванням, а також для генетичного консультування в родинах високого ризику.

Ключові слова: ген TGFBI, кератоепітелін, дистрофія рогівки.

\section{В. Н. Пампуха, Г. И. Дрожжина, Л. А. Лившии}

Исследование мутаций гена TGFBI у больных с дистрофиями стромы роговицы, проживающих в Украине

Резюме

Проанализированы мутащии Arg124Cуs (экзон 4), Thr538Arg, Ala546Thr, Arg555Thr, Arg55Gln (экзон 12), His626Arg (экзон 14) гена TGFBI с использованием метода полимеразной иепной реакиии с последующей рестрикцией у 91 пациента с разными формами дистрофии роговицы и среди 31 клинически здорового индивида из 49 неродственных семей. Полученные результаты свидетельствуют о том, что анализ мутаций в гене TGFBI имеет важное значение в дифференциальной диагностике дистрофий роговицы с прогностическим и терапевтическим применением, а также для генетического консультирования в семьях высокого риска.

Ключевие слова: ген TGFBI, кератоэпителин, дистрофия роговичь

\section{REFERENCES}

1. Skonier J., Neubauer M., Madisen L., Bennett K., Plowman G. D., Purchio A. F. cDNA cloning and sequence analysis of beta ig-h3, a novel gene induced in a human adenocarcinoma cell line after treatment with transforming growth factor-beta // DNA Cell Biol.-1992.-11.-P. 511-522.

2. Escribano J., Hernando N., Ghosh S., CrabbJ., Coca-Prados $M$. cDNA from human ocular ciliary epithelium homologous to beta ig-h3 is preferentially expressed as an extracellular protein in the corneal epithelium // J. Cell Physiol.-1994.-160.-P. 511-521.

3. Klintworth G. K., Enghild J. J., Valnickova Z. Discovery of a novel protein (beta ig-H3) in normal human cornea // Invest. Ophthalmol. Vis. Sci.-1994.-35 (Suppl).-P. 1938.

4. Stone E. M., Mathers W. D., Rosenwasser G. O. D., Holland E. J., Folberg R., Krachmer J. H., Nichols B. E., Gorevic P. D., Taylor C. M., Streb L. M., Fishbaugh J. A., Daley T. E., Sucheski B. M., Sheffield V. C. Three autosomal dominant corneal dystrophies map to chromosome 5q // Nat. Genet.-1994.-6.-P. 47-51.

5. Munier L. F., Korvatska E., Djemai A., Palsier D. L., Zografos L., Pescia G., Schorderet D. F. Keratoepithelin mutation in four 5g31-linked corneal dystrophies // Nat. Genet.-1997.-15.-P. 247251.

6. Le Baron R. G., Bezverkov K. I., Zimber M. P., Pavelec R., Skonier J., Purchio A. F. Beta IG-H3, a novel secretory protein inducible by transforming growth factor-beta, is present in normal skin and promotes the adhesion and spreading of dermal fibroblasts in vitro // J. Invest. Dermatol.-1995.-104.-P. 844- 849.

7. Kim J. E., Kim S. J., Lee B. H., Park R. W., Kim K. S., Kim I. S. Identification of motifs for cell adhesion within the repeated domains of transforming growth factor-beta-induced gene, betaig-h3 // J. Biol. Chem.-2000.-275.-P. 30907-30915.

8. Arnaout M. A., Goodman S. L., Xiong J. P. Coming to grips with integrin binding to ligands // Curr. Opin. Cell Biol.-2002.-14.P. 641-651.

9. Hashimoto K., Noshiro M., Ohno S., Kawamoto T., Satakeda H., Akagawa Y., Nakashima K., Okimura A., Ishida H., Okamoto T., Pan H., Shen M., Yan W., Kato Y. Characterization of a cartilage-derived $66-\mathrm{kDa}$ protein (RGD-CAP/betaig-h3) that binds to collage // Biochim. et Biophys. Acta.-1997.-1355.- P. 303-314.

10. Hanssen E., Reinboth B., Gibson M. A. Covalent and non-covalent interactions of betaig-h3 with collagen VI. Betaig-h3 is covalently attached to the amino-terminal region of collagen VI in tissue microfibrils // J. Biol. Chem.-2003.-278.-P. 24334-24341.

11. Billings P. C., Whitbeck J. C., Adams C. S., Abrams W. R., Cohen A. J., Egelsberg B. N., Howard P. S., Rosenbloom J. 
The transforming growth factor-beta-inducible matrix protein (beta)ig-h3 interacts with fibronectin // J. Biol. Chem.-2002.-277.-P. 28003-28009.

12. Zinn K., McAllister L., Goodman C. S. Sequence analysis and neuronal expression of fasciclin $I$ in grasshopper an Drosophilia // Cell.-1988.-53.-P. 577-587.

13. Clout N., Hohenester E. A model of FAS1 domain 4 of the corneal protein big-h3 gives a clearer view on corneal dystrophies // Mol. Vis.-2003.-9.-P. 440-448.

14. Waring G., Rodrigues M., Laibson R. Corneal dystrophy. Dystrophies of the epithelium, Bowman layer and stromas // Surv. Ophthalmol.-1978.-23.- P. 97-101.

15. Jones M., Zimmerman L. Histopathologic differentiation of granular, Macular and lattice Dystrophies of the cornea // Amer. J. Ophthalmol.-1960.-51.-P. 102-116.

16. Dighiero P., Niel F., Ellies P., D’Hermies F., Savoldelli M., Renard G., Delpech M., Valleix S. Histologic phenotype-genotype correlation of corneal dystrophies associated with eight distinct mutations in the TGFBI gene // Ophthalmology.-2001.-108.-P. 818-823.

17. Maschima Y., Nakamura Y., Noda K., Konishi M., Yamada M., Kudoh J., Shimizu N. A novel mutation at codon 124 (R124L) in the $B G I H 3$ gene associated with superficial variant of granular corneal dystrophy // Arch. Ophthalmol.-1999.-117.-P. 90-93.

18. Pampukha V. M., Drozhyna G. I., Livshits L. A. TGFBI gene mutation analysis in families with hereditary corneal dystrophies from Ukraine // Opthalmologica.-2004.-218.-P. 411-414.

19. Okada M., Yamamoto S., Watanabe H., Inoue Y., Tsujikawa M., Maeda N., Shimomura Y., Nishida K., Kinoshita S., Tano $Y$. Granular corneal dystrophy with homozygous mutations in the kerato- epithelin gene // Amer. J. Ophthalmol.-1998.-126.-P. 169-176.

20. Mashima Y., Konishi M., Nakamura Y., Imamura Y., Yamada M., Ogata T., Kudoh J., Shimizu N. Severe form of juvenile corneal stromal dystrophy with homozygous R124H mutation in the keratoepithelin gene in five Japanese patients // Br. J. Ophthalmol.-1998.-82.-P. 1280-1284.

21. Kanai A., Tonaka M., Kaneno H., NiwaY., Nakajima A. A clinical and histopathological studies of the lattice dystrophy of the cornea // Acta Soc. Ophthalmol. Jap.-1973.-77.-P. 357-367.

22. Dubord P. I., Krachmer I. Diagnosis of the early lattice corneal dystrophy // Arch. Ophthalmol.-1982.-100.-P. 788-790.

23. Майчук Ю. Ф., Орловская Л. Е. Стромальные дистрофии клинические формы и лечение // Офтальмол. журн.-1993.-4.-С. 224-232.

24. Endo S., Nguyen T. H., Fujiki K., Hotta Y., Nakayasu K., Yamaguchi T., Ishida N., Kanai A. Leu518Pro mutation of the beta ig-h3 gene causes lattice corneal dystrophy type I // Amer. J. Ophthalmol.-1999.-128.- P. 104-106.

25. Warren J. F., Abbott R. L., Yoon M. K., Crawford J. B., Spencer $W$. H., Margolis T. P. A new mutation (Leu569Arg) within exon 13 of the TGFBI (BIGH3) gene causes lattice corneal dystrophy type I // Amer. J. Ophthalmol.-2003.-136.-P. 872-878.

26. Chakravarthi S., Kannabiran C., Sridhar M. S., Vemuganti G. K. $T G F B I$ gene mutations causing lattice and granular corneal dystrophies in Indian patients // Invest. Ophthalmol. Vis.-2005.46.-P. 121-125.

27. Stock E., Feder R., O'Grady R., Sugar J., Roth S. Lattice corneal dystrophy type III-A: clinical and histopathologic correlations // Arch. Ophthalmol.-1991.-109.-P. 354-358.

28. Yamamoto S., Okada M., Tsujikawa M., Shimomura Y., Nishida K., Inoue Y., Watanabe H., Maeda N., Kurahashi H., Kinoshita S., Nakamura Y., Tano Y. A kerato-epithelin (beta-ig-h3) mutation in lattice corneal dystrophy type IIIA // Amer. J. Hum. Genet.-1998.- 62.-P. 719-722.

29. Dighiero P., Drunat $S$., Ellies P., D'Hermies F., Savoldelli M., Renard G., Delpech M., Valleix S. A new mutation (A546T) of the big-h3 gene responsible for French lattice corneal dystrophy type IIIA // Amer. J. Ophthalmol.-2000.-129.-P. 248-251.

30. Munier F. L., Frueh B. E., Othenin-Girard P., Uffer S., Cousin P., Wang M. X., Heon E., Black G. C. M., Blasi M. A., Balestrazzi E., Lorenz B., Escoto R., Barraquer R., Hoeltzenbein M., Gloor B., Fossarello M., Singh A. D., Arsenijevic $Y$., Zografos L., Schorderet D. F. BIGH3 mutation spectrum in corneal dystrophies // Invest. Ophthalmol. Vis. Sci.-2002.-43.-P. 949-954.

31. Stewart H., Black G. C., Donnai D., Bonshek R. E., McCarthy J., Morgan S., Dixon M. J., Ridgway A. A. A mutation within exon 14 of the TGFBI (BIGH3) gene on chromosome $5 \mathrm{q} 31$ causes an asymmetric, late-onset form of lattice corneal dystrophy // Ophthalmology.-1999.-106.-P. 964-970.

32. Schmitt-Bernard C., Guittard C., Arnaud B., Demaille J., Argiles A., Claustres M., Tuffery-Giraud S. BIGH3 exon 14 mutations lead to intermediate type I/IIIA of lattice corneal dystrophies // Invest. Ophthalmol. Vis. Sci.-2000.-41.-P. 1302-1308.

33. Fujiki K., Hotta Y., Nakayasu H. A new L527R mutation of the beta-IGH3 gene in patients with lattice corneal dystrophy with deep stromal opacities // Hum. Genet.-1998.-103.-P. 283-286.

34. Groenouw A. Knotchenformige Hornhauttrubungen (noduli corneae) // Arch. Augenheilk.-1890.-21.-P. 281-289.

35. Weidle E. Epitheliale und stromale Hornhautdystrophien // Der Ophthalmologe.-1996.-93.-P. 754-767.

36. Witschel H. Hornhautdystrophien und Molekulargenetik // Der Ophthalmologe.-2002.-99.-P. 415-417.

37. Smolin G., Thoft R. Corneal dystrophies and degeneration // The cornea / Third ed.-Boston etc., 1994.-P. 499-524.

38. Stewart H. S., Ridgway A. E., Dixon M. J., Bonshek R., Parveen R., Black G. Heterogeneity in granular corneal dystrophy: identification of three causative mutations in the TGFBI (BIGH3) gene-lessons for corneal amyloidogenesis // Hum. Mutat.-1999.-14.-P. 126-132.

39. Holland E., Daya S. M., Stone S. M. Avellino corneal dystrophy: clinical manifestation and natural history // Ophthalmology.1992.- 99.-P. 1564- 1568.

40. Akiya S., Takahashi H., Nakano N., Hirose N., Tokuda Y. Granular-lattice (Avellino) corneal dystrophy // Ophthalmologica.-1999.-213.-P. 58-62.

41. Rodrigues M., Krachmer J. Recent advances in corneal stromal dystrophies // Cornea.-1988.-7.-P. 19-29.

42. Ruusuvaara P., Setala K., Tarkannen A. Granular corneal dystrophy with early stromal manifestation. A clinical and electron microscopial study // Acta Ophthalmologica.-1990.-68.-P. 525531.

43. Okada M., Yamamoto S., Tsujikawa M., Watanabe H., Inoue Y., Maeda N., Shimomura Y., Nishida K., Quantock A. J., Kinoshita S., Tano $Y$. Two distinct kerato-epithelin mutations in Reis-Bucklers corneal dystrophy // Amer. J. Ophthalmol.1998.-126.-P. 535-542.

44. Rozzo C., Fossarello M., Galleri G., Sole G., Serru A., Orzalesi N., Serra A., Pirastu M. A common beta-ig-h3 gene mutation (delta-f540) in a large cohort of Sardinian Reis Bucklers' corneal dystrophy patients // Hum. Mutat.-1998.12.-P. 215-216.

45. Afshari N. A., Mullally J. E., Afshari M. A., Steinert R. F., Adamis A. P., Azar D. T., Talamo J. H., Dohlman C. H., Dryja T. $P$. Survey of patients with granular, lattice, Avellino, and 
Reis-Becklers corneal dystrophies for mutations in the BIGH3 and gelsolin genes // Arch. Ophthalmol.-2001.-119.P. 16-22.

46. Weidle E. Differential Diagnose der Hornhautdystrophien vom Groenouw Typ I, Reis-Bucklers und Thiel-Benke // Forschritt Ophthalmol.-1989.- 106.-P. 65-71.

47. Weidle E. Honeycomb-chaped corneal dystrophy of Thiel and Benke. Reclassification and distinction from Reis-Bucklers corneal dystrophy // Klin. Monatsbl. Augenheilk.-1999.-214.P. 125-135.

48. Yee R. W., Sullivan L. S., Lai H. T., StockE. L., Lu Y., Khan M. $N$., Blanton S. H., Daiger S. P. Linkage mapping of Thiel-Behnke corneal dystrophy (CDB2) to chromosome 10q23-q24 // Genomics.-1997.-46.-P. 152-154.

49. Дрожжина Г. И., Вит В. В., Думброва Н. Е. Молекулярно-генетический и клинико-морфологический анализ больных с решетчатой наследственной дистрофией роговицы // Офтальмол. журн.-2002.-2.-C. 37-41.

50. Маниатис Т., Фрич Э., Сэмбрук Дж. Молекулярное клонирование.-М.: Мир, 1984.-420 с.

51. Saiki R. K., Gelfand D. H., Stoffel S., Scharf S. J., Higuchi R., Horn G. T., Mullis K. B., Erlich H. A. Primer directed enzymatic amplification of DNA with a thermostable DNA polymerase // Science.-1988.- 239, N 8580.-P. 487-491.

52. Othenin-Girard P., Frueh-Epstein B., Gloor B. Identification of mutations in autosomal dominant corneal dystrophies // Invest. Ophthalmol. Vis. Sci.-1999.-40 (Suppl).-P. 563.

UDC 575.11:577.21:576.31:617.713-007.17-02 Received 04.06.07 